\title{
Religieuze voorgangers tussen Schrift en recht
}

\author{
Botsing van de godsdienstvrijheid en het gelijkheidsbeginsel in \\ Nederland ${ }^{*}$
}

Kirsten Smeets \& Carl Sterkens

\begin{abstract}
In onze westerse samenleving is het recht op vrijheid van godsdienst en levensovertuiging een algemeen aanvaard principe. Het toepassingsbereik van dit recht en de positie daarvan in relatie tot andere grondrechten zijn echter tot op de dag van vandaag bron van discussie. Menigmaal worden geschillen hierover voor de rechter gebracht. In deze bijdrage richten we ons op de botsing van de vrijheid van godsdienst, de vrijheid van meningsuiting en het gelijkheidsbeginsel ingeval er sprake is van discriminerende uitspraken door religieuze voorgangers op grond van hun religieuze overtuiging. Welke vrijheid van spreken hebben Nederlandse religieuze voorgangers wanneer hun opvattingen botsen met het discriminatieverbod?
\end{abstract}

\section{Probleemstelling: discriminerende uitspraken van religieuze voorgangers}

De meeste religieuze gemeenschappen staan niet meteen bekend als grote voorvechters van homorechten, om het eufemistisch uit te drukken. Regelmatig doen religieuze voorgangers of vertegenwoordigers van religieuze instituties uitspraken over homoseksualiteit die volgens anderen discriminerend, aanstootgevend of op zijn minst ongelukkig geformuleerd zijn. Soms lijkt het erop dat deze uitspraken juridisch niet (kunnen) worden veroordeeld, precies omdat ze binnen een religieus kader plaatsvinden. De voorbeelden zijn legio; de meest spraakmakende juridische zaken zijn wellicht die van de COC Nederland tegen kardinaal Simonis in 1979, en het initiatief van het Openbaar Ministerie om in 1999 uitspraken van (thans kardinaal) Wim Eijk te toetsen op hun (mogelijk) discriminerend karakter. Maar er zijn ook recentere rechtszaken, zoals die tegen een fictieve christelijke voorganger die in naar eigen zeggen satirisch bedoelde stukken op internet homoseksuelen beledigde en zelfs aanzette tot haat jegens hen. ${ }^{1}$ Binnen de kerken zijn er natuurlijk ook oproepen voor juist meer begrip en openheid voor homoseksualiteit en de diversiteit van relatievormen. Opvallend is het recente document van de bisschop van Antwerpen, die in de bredere context van relatievorming en gezin opmerkt 'hoe aanstootgevend de taal van de Kerk tegenover bepaalde situaties of personen wel kan overkomen' (p. 14) en dat 'deze situaties meer respect en een

\footnotetext{
* $\quad$ De auteurs danken mr. drs. T. van Kooten - die eerder publiceerde over dit thema en optrad als advocaat in meerdere zaken op dit terrein - voor zijn waardevol commentaar op deze bijdrage. Alle onvolkomenheden blijven uiteraard voor rekening van de auteurs. 
meer genuanceerd oordeel [verdienen] dan uit de taal van bepaalde kerkelijke documenten mag blijken' (p. 15). ${ }^{2}$

In deze bijdrage bespreken we de wijze waarop drie grondrechten ten opzichte van elkaar worden afgewogen in het geval van (vermeende) discriminerende uitspraken door religieuze voorgangers. Meer concreet gaat het om de volgende drie grondrechten: de vrijheid van godsdienst, de vrijheid van meningsuiting en het gelijkheidsbeginsel. De twee zaken die we daarbij exemplarisch uitwerken, spelen een grote rol in de jurisprudentie en zijn bovendien twee van de meest recente (en dus relatief zeldzame) rechtszaken waarin religieuze voorgangers van discriminatie werden beschuldigd. De eerste betreft een interview met de Rotterdamse imam Khalil El Moumni dat op 3 mei 2001 werd uitgezonden door het tv-programma NOVA. De gelijkstelling van de imam van homoseksualiteit met een afwijking dan wel ziekte leidde tot tientallen aangiften van discriminatie bij het Openbaar Ministerie (OM). Maar in de rechtspraak die volgde werd El Moumni zowel door de Rechtbank Rotterdam als door het gerechtshof in Den Haag vrijgesproken.

De tweede zaak betreft een ingezonden brief van dominee E.S. Herbig die werd gepubliceerd in De Twentsche Courant Tubantia. Daarin noemt deze pinkstervoorganger homofilie een 'vieze en vuile zonde', maar Herbig werd in 2003 door de Hoge Raad vrijgesproken van belediging.

Betekenen deze vrijspraken dat religieuze voorgangers alles mogen zeggen, zolang ze zich maar op de godsdienstvrijheid en/of de vrijheid van meningsuiting beroepen? Of bestaan er wel degelijk grenzen? Een antwoord moet worden gezocht in de afweging van de genoemde grondrechten en de maatstaf die de rechter daarvoor gebruikt. In de eerste paragraaf schetsen we de inhoud van de drie grondrechten en hun historische verankering. Onze interesse is weliswaar niet historisch, maar we verwijzen naar de verschuivingen en cruciale veranderingen van de gebruikte begrippen om de inhoud van de grondrechten voor de casussen van imam El Moumni en dominee Herbig te verduidelijken. In de tweede paragraaf schetsen we twee maatschappelijke ontwikkelingen die van invloed zijn op de afweging van de grondrechten in Nederland. Vervolgens beschrijven we in de derde paragraaf de rechtsafweging in de zaken El Moumni en Herbig. In de vierde paragraaf formuleren we enkele afwegingsprincipes in het geval dat religieuze voorgangers discrimineren, om af te sluiten met een antwoord op de vraag die in deze bijdrage centraal staat: hoe ver reikt de vrijheid van spreken voor religieuze voorgangers in Nederland.

2 J. Bonny, Synode over het gezin. Verwachtingen van een diocesane bisschop, Antwerpen 2014. Zie ook het tussentijds rapport van de 3e Buitengewone Synode over huwelijk en gezin: Relatio post disceptationem - Synode 2014, Rome: Libreria Editrice Vaticana 2014, nrs. 50-52. Voor het slotdocument werd evenwel (nipt) geen vereiste twee derde meerderheid gevonden voor het voorgestelde $\mathrm{nr}$. 55, waarin werd opgeroepen tot een respectvolle en gevoelige aanvaarding van personen 'met een homoseksuele gerichtheid' en tegen elke vorm van onrechtvaardige discriminatie. 'Relatio Synodi' della III Assemblea generale straordinaria del Sinodo dei Vescovi: 'Le sfide pastorali sulla famiglia nel contesto dell' evangelizzazione' (5-19 ottobre 2014), Rome 2014. 


\section{Historische context van drie vrijheidsrechten}

De drie grondrechten die bij religieus gefundeerde discriminatie met elkaar botsen, behoren tot de eerste generatie van mensenrechten. Dit zijn de politieke en burgerlijke vrijheidsrechten die aan het eind van de achttiende eeuw werden geformuleerd om de vrijheid van het individu te beschermen. In deze paragraaf beschrijven we kort wat de godsdienstvrijheid, de vrijheid van meningsuiting en het gelijkheidsbeginsel inhouden. We verwijzen naar het verleden om daarmee de inhoud en de evolutie van deze grondrechten in grote lijnen duidelijk te maken, alsook om hun diepe historische en maatschappelijke verankering te illustreren.

\section{Godsdienstvrijheid}

Wat is godsdienstvrijheid? De Universele verklaring van de rechten van de mens (UVRM, art. 18) en in navolging daarvan het Europees Verdrag tot bescherming van de rechten van de mens en de fundamentele vrijheden (EVRM, art. 9) vermelden daarover het volgende: 'Een ieder heeft recht op vrijheid van gedachte, geweten en godsdienst; dit recht omvat tevens de vrijheid om van godsdienst of overtuiging te veranderen, alsmede de vrijheid hetzij alleen, hetzij met anderen, zowel in het openbaar als privé zijn godsdienst te belijden of overtuiging tot uitdrukking te brengen in erediensten, in onderricht, in praktische toepassing ervan en in het onderhouden van geboden en voorschriften.'

In deze formulering valt op dat godsdienst niet alleen wordt beschermd, maar dat ook het recht om van godsdienst te veranderen wordt vermeld, en het recht om geen godsdienst te hebben wordt geïmpliceerd. Dit laatste valt immers onder de vrijheid van overtuiging dat er geen God bestaat. Daarnaast valt het impliciete onderscheid tussen forum internum en forum externum op. ${ }^{3}$ Het forum internum verwijst naar de absolute vrijheid om bepaalde (religieuze) overtuigingen te hebben, volgens sommigen inclusief het recht om niet te kunnen worden gedwongen om de eigen opvattingen kenbaar te maken. Het forum externum omvat de vrijheid om uitdrukking te geven aan (religieuze) overtuigingen en daarmee alle manifestaties van religiositeit. Het forum internum kent doorgaans een veel sterkere juridische bescherming dan het forum externum, zoals onder meer blijkt uit de rechtspraak van het Europees Hof voor de Rechten van de Mens (EHRM). De rechtspraak van het EHRM is van belang voor de afweging van de grondrechten, omdat de eventuele juridische gevolgen van een arrest moeten worden verwerkt in de nationale wetgevingen van de lidstaten van de Raad van Europa. Dit geldt ongeacht de gegrondheid van de klacht en ongeacht de betrokkenheid van een land in een rechtszaak. ${ }^{4}$ In Nederland wordt de vrijheid van godsdienst en levensovertuiging onder meer bepaald in artikel 6 van de Grondwet.

3 P.A.M. Taylor, Freedom of Religion. UN and European Human Rights Law and Practice, Cambridge: Cambridge University Press 2005; cf. J.A. van der Ven, Human Rights or Religious Rules?, Leiden: Brill 2010, p. 279.

4 T. van Kooten, 'Religieuze gemeenschappen in het licht van artikel 9 EVRM: vrijheid en gebondenheid', in: H. Post \& G. van der Schyff (red.), Godsdienstvrijheid in de Nederlandse rechtsorde. Nationale en Europese perspectieven, Oisterwijk: Wolf Legal Publishers 2014, p. 257-285. 
Een belangrijke voorwaarde voor de vrijheid van godsdienst is een scheiding tussen het domein van de religie en het domein van de overheid. Het theoretische onderscheid tussen een spiritueel en een wereldlijk domein (en dus niet de scheiding van kerk en staat als dusdanig) ontstond al snel nadat het christendom door de Romeinse keizer Theodosius tot staatsgodsdienst was verheven. Zo formuleerde paus Gelasius I (492-496) in verwijzing naar Lukas 22:385 de 'tweezwaardenleer' van de kerk. In de bul Unam Sanctam (1302) tekende paus Bonifatius VIII (1294-1303) zijn eigen interpretatie van de tweezwaardenleer op in het kader van zijn machtsstrijd met de Franse koning. Deze interpretatie hield in dat de paus van Christus het gezag had gekregen om zowel over de spirituele als de temporele sfeer invloed (gesymboliseerd als een zwaard) uit te oefenen. ${ }^{6}$ Hoewel er dus al vroeg een theoretisch onderscheid werd gemaakt tussen spirituele en temporele sfeer, bleven kerk en staat in de praktijk nog eeuwenlang met elkaar vervlochten. Tijdens de Europese godsdienstoorlogen van de zestiende en de zeventiende eeuw bemoeiden overheden zich actief met de vervolging van religieuze dissidenten. Velen werden gedwongen tot een leven in ballingschap of moesten hun geloof bekopen met de dood.

Dit religieuze geweld zette denkers als Thomas Hobbes (1588-1679) en John Locke (1632-1704) ertoe aan om de verhouding tussen kerk en staat te heroverwegen. Hobbes keerde de machtsprioritering binnen het tweezwaardenmodel om. ${ }^{7}$ De geestelijke macht van de kerk diende volgens hem ondergeschikt te zijn aan de wereldlijke macht van de overheid, omdat deze laatste de vrede en de veiligheid van alle burgers diende te waarborgen. Volgens Locke deed de seculiere overheid er voor de bevordering en het behoud van de vrede goed aan om religieuze pluraliteit te tolereren in plaats van religieuze uniformiteit op te leggen. Een functionele scheiding van kerk en staat was hiervoor noodzakelijk. ${ }^{8}$ Omdat de staat geen legitieme macht heeft over religie (net zomin als de kerk over de wereldlijke sfeer), diende de overheid een neutrale positie in te nemen ten opzichte van religieuze diversiteit. Slechts op grond van seculiere redenen zou de overheid religieuze stromingen of praktijken mogen beperken. Locke maakte hierbij wel de kanttekening dat de staat zijn autoriteit niet mag misbruiken om (bepaalde) religieuze bewegingen te onderdrukken onder het voorwendsel van 'het algemeen welzijn'. 9

De ideeën van Locke over de scheiding van kerk en staat en de daarmee verbonden godsdienstvrijheid vonden veel aanhang in Europa. Maar ook al eerder, met name in de Pacificatie van Gent (1576) en in de Unie van Utrecht (1579), werd in de Nederlanden vastgelegd dat ieder individu vrij was om de eigen religie te belijden. De gereformeerde kerk had echter nog een geprivilegieerde positie. Ze was een publieke kerk, had de kerkgebouwen in Nederland tot haar beschikking en

$5 \quad$ 'Kijk Heer, hier zijn twee zwaarden' (NBV).

6 R. Blackford, Freedom of Religion \& The Secular State, West Sussex: John Wiley \& Sons 2012, p. 27.

7 Blackford 2012, p. 32.

$8 \quad$ M. Goldie, Locke: Political Essays, Cambridge: University Press 1997, p. 216.

9 J. Locke, A Letter concerning Toleration (1e publ. 1689), Indianapolis: Hackett 1983, p. 42. 
ontving financiële steun van de overheid. ${ }^{10}$ De keerzijde daarvan was dat de overheid zich sterk mengde met haar interne aangelegenheden.

In 1796 werd door de Eerste Nationale Vergadering van de Bataafse Republiek een einde gemaakt aan de bevoorrechte positie van de gereformeerde kerk door de scheiding van kerk en staat wettelijk vast te leggen en andere kerkgenootschappen te erkennen. ${ }^{11}$ De legalisatie van 1796 impliceerde niet alleen het recht op godsdienstvrijheid, maar stelde de samenleving ook voor de uitdaging van de multiculturaliteit. Niet op zijn minst werd de religieuze pluraliteit een uitdaging voor de concrete toepassing van het recht op godsdienstvrijheid zelf, hoe paradoxaal dit ook mag klinken. De reden is eenvoudig: naarmate de maatschappelijke consensus over wat religie ís of dient te zijn verdwijnt, wordt het moeilijker om de godsdienstvrijheid (in al haar dimensies) concreet toe te passen.

\section{Vrijheid van meningsuiting}

Het recht op vrijheid van godsdienst en levensbeschouwing omvat het recht om een (religieuze) overtuiging te belijden en te beleven. In die zin bestaat er een duidelijke overlap tussen de vrijheid van meningsuiting en de godsdienstvrijheid. Maar de vrijheid van meningsuiting wordt ook afzonderlijk beschermd, zoals in de UVRM (art. 19) en het EVRM (art. 10 sub 1) is geformuleerd: 'Een ieder heeft recht op vrijheid van meningsuiting. Dit recht omvat de vrijheid een mening te koesteren en de vrijheid om inlichtingen of denkbeelden te ontvangen of te verstrekken, zonder inmenging van enig openbaar gezag en ongeacht grenzen.'

In de Nederlandse Grondwet staat de vrijheid van meningsuiting bekend als de vrijheid van drukpers, wat het recht op de vrijheid van het openbaren en het verspreiden van alle gedachten en gevoelens zonder voorafgaand verlof omvat (art. 7 Grondwet). Net als de formulering van de godsdienstvrijheid is het recht op vrijheid van meningsuiting op zich genomen 'neutraal' ten opzichte van religie, omdat het zowel religieuze als antireligieuze overtuigingen kan beschermen en ondersteunen. Deze dubbele verhouding ten opzichte van religie is ook in de geschiedenis terug te vinden. De vrijheid voor het uiten van een overtuiging, van religieuze aard of niet, werd tegen de achtergrond van de Franse Revolutie vastgelegd in de Déclaration des droits de l'homme et du citoyen (1789). Het recht op de vrije communicatie van ideeën en meningen werd als 'één van de meest kostbare rechten van de mens' gekwalificeerd. ${ }^{12}$

Hoewel dit recht ook gold voor religieuze uitingen, zag men dit recht vooral als een garantie om zich ook te kunnen uiten tegen religie. Zo maakte men zich los van het eeuwenoude verbod op godslastering dat zowel door kerk als staat was opgelegd. Godslastering was namelijk niet alleen een belediging van God, maar werd ook als vijandigheid tegen de politieke orde van de (door het christendom gedomineerde) samenleving beschouwd. Tegenwoordig wordt het verbod op

10 F.T. Oldenhuis e.a., Schurende relaties tussen recht en religie, Assen: Van Gorcum 2007, p. 7.

11 J. Israel, The Dutch Republic. Its Rise, Greatness and Fall 1477-1806, Oxford: Clarendon press 1998, p. 1122-1130.

12 Art. XI van de Déclaration des droits de l'homme et du citoyen, www. assemblee-nationale.fr/ histoire/dudh/1789.asp. 
godslastering door de West-Europese landen waar het verbod nog in de wet is opgenomen, nauwelijks meer toegepast. Dit is indirect het gevolg van de toenemende invloed van de vrijheid van meningsuiting en volgens sommigen ook van het verdwijnen van een uniforme religieuze samenleving. ${ }^{13}$

Wat houdt de vrijheid van meningsuiting nu in stand? Paul Cliteur ${ }^{14}$ noemt twee belangrijke motieven voor de vrijheid van meningsuiting. Vooreerst wordt de vrije ontwikkeling van het individu geremd als anderen voorschrijven wat men wel en niet kan zeggen. Als elke uitspraak kan worden onderdrukt omdat iemand anders deze als beledigend ervaart, wordt de ruimte voor communicatie al te makkelijk ingeperkt. Wat voor de een beledigend is, kan voor een ander immers een waardevolle overtuiging zijn. Elke inperking van de vrijheid van meningsuiting zou erin resulteren dat gewaagde en nieuwe ideeën die tegen de consensus ingaan niet de kans krijgen om zich te verspreiden of te ontwikkelen.

Ten tweede werpt de vrijheid van meningsuiting in maatschappelijk opzicht haar vruchten af voor de ontwikkeling van wetenschap, cultuur en religie. John Stuart Mill (1806-1873) sprak in dit verband over de marketplace of ideas waar de waarheid vrijelijk kan worden gezocht. ${ }^{15}$ Vrije communicatie van ideeën was volgens Mill een cruciaal onderdeel van elke legitieme representatieve democratie. Vrije communicatie kan het gevaar beperken dat sommigen, inclusief de overheid zelf, de rechten van het individu zou onderdrukken ten gunste van andere belangen.

Toch blijft de vraag hoe ver de vrijheid van meningsuiting reikt. Staat de vrijheid van meningsuiting werkelijk boven alles? Voor Mill lag de beperking van de vrijheid van meningsuiting in het relatief abstracte 'harm principle'. Handelingen en uitspraken van individuen mogen worden beperkt als ze schade toebrengen aan anderen. Ook in de Déclaration des droits de l'homme et du citoyen wordt reeds vermeld dat 'vrijheid daaruit bestaat alles te kunnen doen wat een ander niet schaadt'. ${ }^{16}$ Er is dus inperking mogelijk, maar de huidige wettelijke formulering van de vrijheid van meningsuiting verschilt in de diverse Europese landen en is ook onderhevig aan nogal wat interpretatie. Aantasting van de goede smaak en belediging vallen veelal niet onder de beperking van de vrijheid van meningsuiting, maar laster, smaad, het aanzetten tot haat en opruiing wel. Om tot die kwalificaties te komen blijft de context van belang. Als de rechtsstaat namelijk elke uiting van (in)directe vijandigheid zou moeten verbieden, zou dit voor veel uitspraken gelden, inclusief talrijke passages uit heilige geschriften zoals de Bijbel en de Koran.

13 In 2013 werd het wetsvoorstel om het verbod op godslastering uit het Wetboek van Strafboek te schrappen achtereenvolgens door de Tweede (16 april 2013) en de Eerste Kamer (3 december 2013) aangenomen. Cf. B.A.M. van Stokkom, H.J.B. Sackers \& J.-P. Wils, Godslastering, discriminerende uitingen wegens godsdienst en haatuitingen: een inventariserende studie, Den Haag: Boom Juridische uitgevers 2007.

14 P. Cliteur, The Secular Outlook: In Defense of Moral and Political Secularism, Oxford: WileyBlackwell 2010, p. 138-140.

15 J.S. Mill, On Liberty, Londen: Penguin 2003, p. 77-96.

16 Art. IV van de Déclaration des droits de l'homme et du citoyen: 'La Liberté consiste à pouvoir faire tout ce qui ne nuit pas à autrui: ainsi l'exercice des droits naturels de chaque homme n'a de bornes que celles qui assurent aux autres Membres de la Société, la jouissance de ces mêmes droits. Ces bornes ne peuvent être déterminées que par la Loi.' 


\section{Het gelijkheidsbeginsel}

Het derde principe dat van belang is om discriminerende uitspraken van religieuze voorgangers te evalueren, is het gelijkheidsbeginsel, en daaruit volgend het non-discriminatiebeginsel. De UVRM (art. 1) opent niet voor niets met: 'Alle mensen worden vrij en gelijk in waardigheid en rechten geboren.' De mensenrechten zouden immers de kern van hun betekenis verliezen als ze niet gelijkelijk aan iedereen zouden toekomen. ${ }^{17}$ In het daaropvolgende artikel wordt dit gelijkheidsbeginsel negatief gespecificeerd als het non-discriminatiebeginsel: 'Een ieder heeft aanspraak op alle rechten en vrijheden, in deze Verklaring opgesomd, zonder enig onderscheid van welke aard ook, zoals ras, kleur, geslacht, taal, godsdienst, politieke of andere overtuiging, nationale of maatschappelijke afkomst, eigendom, geboorte of andere status' (art. 2 UVRM; cf. art. 14 EVRM). Ook de Nederlandse Grondwet begint met het gelijkheidsbeginsel en het daaruit volgende discriminatieverbod. Daarnaast is op talrijke plaatsen in zowel strafrecht als burgerlijk recht antidiscriminatiewetgeving te vinden.

Hoewel het gelijkheidsbeginsel tegenwoordig een vanzelfsprekend recht lijkt, ging dit idee het westerse denken pas in de loop van de twintigste eeuw domineren. ${ }^{18}$ Sinds de initiële formulering ervan in 1789 in de Déclaration des droits de l'homme et du citoyen is het gelijkheidsbeginsel inhoudelijk grondig veranderd. We noemen drie grote veranderingen. De Franse Revolutie ageerde tegen de middeleeuwse feodale maatschappij, waarin het onderscheid tussen de standen door God was bepaald. Armen konden niet op dezelfde behandeling rekenen als burgers van goede afkomst. Maar met artikel VI van de Déclaration werden 'alle' burgers gelijk voor de wet. ${ }^{19}$ Vrouwen, kinderen en krankzinnigen behoorden echter niet tot de categorie van burgers. Pas later in de twintigste eeuw veranderde dit. Een tweede verandering is de verschuiving van verticale naar horizontale werking van het gelijkheidsbeginsel.

Aanvankelijk had het gelijkheidsbeginsel vooral betrekking op de beperking van de macht van de overheid ten opzichte van haar burgers (de verticale werking), maar steeds vaker werd er een beroep op gedaan in de verhouding tussen burgers onderling (de horizontale werking). Een derde daarvan te onderscheiden, maar niet gescheiden, evolutie is de overgang van absolute rechtsgelijkheid naar materieel gelijke behandeling. Aanvankelijk werd het gelijkheidsbeginsel verstaan als absolute rechtsgelijkheid: alle burgers zijn gelijk voor de wet en dienen gelijk behandeld te worden, ongeacht individuele verschillen of groepskenmerken.

In Nederland veranderde deze opvatting geleidelijk met de overgang van de liberale nachtwakersstaat (achttiende/negentiende eeuw) naar de verzorgingsstaat (twintigste eeuw). Vanuit het streven naar sociale rechtvaardigheid richtte de overheid zich steeds meer op het verminderen van ongelijkheid tussen diverse maatschappelijke groepen. In toenemende mate ging de overheid tussen burgers

18 Loenen 1998, p. 9.

19 Art. VI van de Déclaration des droits de l'homme et du citoyen: '(...) Tous les Citoyens étant égaux à ses yeux, sont également admissibles à toutes dignités, places et emplois publics, selon leur capacité, et sans autre distinction que celle de leurs vertus et de leurs talents.' 
differentiëren in haar economisch, sociaal en cultureel beleid. De huidige Nederlandse antidiscriminatiewetgeving geeft daarom niet alleen uitdrukking aan het gelijkheidsbeginsel, maar geeft tevens blijk van een toenemend besef dat onderscheid in behandeling nodig kan zijn om ongelijkheid te verminderen. ${ }^{20}$

\section{Botsing van grondrechten in een veranderende samenleving}

Geen van de drie genoemde universele rechten is 'absoluut'. Hoewel hun sterke positie duidelijk wordt uit hun lange historische wortels en de brede maatschappelijke inbedding, wordt de inperking ervan niet bij voorbaat uitgesloten. Daarnaast zijn de concrete implicaties van de genoemde rechten niet altijd eenduidig vast te stellen. En tot slot zijn de drie grondrechten principieel gelijkwaardig: ze verhouden zich niet in een hiërarchische rangorde. ${ }^{21}$ Deze kenmerken verklaren waarom er relatief makkelijk wrijving tussen genoemde grondrechten ontstaat. En soms komen ze zelfs regelrecht in botsing met elkaar. De vrijheid van godsdienst en de vrijheid van meningsuiting werden bijvoorbeeld tegen elkaar uitgespeeld door de verdediging in de rechtszaak tegen Geert Wilders in 2011. De grond van de zaak ging echter over de botsing tussen de vrijheid van meningsuiting en het gelijkheidsbeginsel. Wilders werd immers vervolgd op basis van de aanklacht dat hij zich schuldig maakte aan het oproepen tot haat tegenover en discriminatie van moslims. Onder meer uitspraken waarin hij de islam een fascistische ideologie noemde en de wens uitsprak om de Koran te verbieden waren aanleiding voor de aanklacht. Op 23 juni 2011 werd hij door de rechtbank van Amsterdam vrijgesproken. De gewraakte uitlatingen werden weliswaar 'grof en denigrerend' maar 'niet opruiend' bevonden. ${ }^{22}$

De vrijheid van godsdienst en het non-discriminatiebeginsel kwamen onder meer met elkaar in aanvaring toen een moslima het verbod van een katholieke school op het dragen van een hoofddoek niet accepteerde. ${ }^{23}$ En voorbeelden van de wrijving tussen de vrijheid van meningsuiting en het gelijkheidsbeginsel zijn talrijk. $\mathrm{Nu}$ lijken deze grondrechten de laatste decennia steeds vaker met elkaar in botsing te komen. Hoe komt dat? Twee maatschappelijke ontwikkelingen dragen daartoe bij: religieuze pluralisering en maatschappelijke polarisering.

20 De Algemene wet gelijke behandeling (AWGB) sluit zogenoemde 'positieve actie' niet uit. Voor een discussie over de begrippen 'discriminatie' versus 'onderscheid' zie R. Holtmaat, 'Discriminatie of onderscheid', in: M.L.M. Hertogh \& P.J.J. Zoontjens (red.), Gelijke behandeling: principes en praktijken, Nijmegen: Wolf Legal Publishers 2006.

21 L.J. Koffeman, Het goed recht van de kerk. Een theologische inleiding op het kerkrecht, Kampen: Kok 2009, p. 298.

22 ECLI:NL:RBAMS:2011:BQ9001.

23 Het hoofddoekverbod werd door de Rechtbank Amsterdam in hoger beroep op 6 september 2011 niet onrechtmatig bevonden (ECLI:NL:GHAMS:2011:BR6764). Over botsingen tussen de godsdienstvrijheid en het gelijkheidsbeginsel, zie H. Post, Gelijkheid als nieuwe religie: een studie over het spanningsveld tussen godsdienstvrijheid en gelijkheid, Nijmegen: Wolf Legal Publishers 2010. 


\section{Religieuze pluralisering}

Vooreerst komen de grondrechten vaker met elkaar in conflict door de toegenomen diversiteit op religieus en cultureel vlak. De religieuze en culturele eenduidigheid is de afgelopen decennia sterk afgenomen door de globalisering, die de geografische grenzen van culturen heeft vervaagd, en de mondialisering, die inhoudelijke grenzen tussen culturen heeft gerelativeerd. ${ }^{24}$ De multiculturele samenleving heeft een grote diversiteit aan religieuze en culturele waarden, normen en overtuigingen. Wanneer deze met elkaar botsen, worden de vrijheid van meningsuiting en het gelijkheidsbeginsel relatief makkelijk ingeroepen. Verder worden de interpretatie en de toepassing van de vrijheid van godsdienst moeilijker naarmate de maatschappelijke consensus over wat religie mag en kan zijn afneemt. Door secularisering en religieuze pluralisering wordt religie relatiever en subjectiever. Hierdoor ontstaat onduidelijkheid over het toepassingsbereik van de godsdienstvrijheid. Er rijzen bijvoorbeeld vragen als: wat verstaan we eigenlijk onder godsdienst? ${ }^{25}$ Wanneer is er sprake van een religieuze uiting? En wanneer is het recht op godsdienstvrijheid dus in het spel? Bovendien daalt de waarde van het recht op bescherming van godsdienst wanneer godsdienst als rechtsbegrip vervaagt. Immers, is het niet onzinnig om iets wettelijk te beschermen wat niet lijkt te bestaan?

Naarmate de reikwijdte van het begrip religie meer ter discussie komt te staan, neemt het aantal botsingen tussen de godsdienstvrijheid en de andere vrijheidsrechten dan ook toe. De aantasting van de godsdienstvrijheid wordt namelijk gemakkelijker door een beroep te doen op grondrechten die relatief eenduidiger worden geïnterpreteerd, zoals de vrijheid van meningsuiting of het gelijkheidsbeginsel.

\section{Maatschappelijke polarisering}

Een tweede ontwikkeling die bijdraagt aan de toegenomen wrijving tussen de drie grondrechten is de maatschappelijke polarisering. De spanningen tussen groepen met verschillende waarden en normen kunnen zo hoog oplopen dat Huntington zelfs spreekt van een clash of civilisations. ${ }^{26}$ In Nederland bestaat er sinds de arbeidsmigratie die plaatsvond tussen 1955 en 1980 een gevarieerd palet aan culturele en religieuze tradities. Met name de komst van de islam lijkt in Nederland te hebben geleid tot polarisering van het debat. Het huidige aantal moslims,

24 B. Badie, 'Mondialisation. Les termes du débat', in: L' Etat du monde. Annuaire économique et géopolitique mondial, Parijs 1994, p. 570-573. Zie ook S. van Bijsterveld, Overheid en godsdienst. Herijking van een onderlinge relatie, Nijmegen: Wolf Legal Publishers 2009, p. 27.

25 Een voorbeeld hiervan is de discussie omtrent de erkenning van het kopimisme. De Zweedse instantie voor wettelijke, financiële en administratieve diensten (Kammarkollegiet) erkende op 4 januari 2012 het kopimisme als religieuze beweging, een erkenning waaraan een aantal fiscale voordelen verbonden zijn. Het kopimisme stelt het kopiëren en verspreiden van informatie als heilig levensdoel en ziet ctrl+c en ctrl+v als heilige symbolen.

26 S.P. Huntington, The Clash of Civilisations and the Remaking of World Order, New York: Simon \& Schuster 1996. 
naar schatting $850.000,{ }^{27}$ komt voor een groot deel voor rekening van de Turkse en Marokkaanse migranten.

De perceptie van economische, politieke of culturele bedreiging door deze groep relatieve nieuwkomers, alsook hun (vermeende) afwijking van de Nederlandse waarden, normen en overtuigingen, hebben geleid tot exclusionaire reacties onder de autochtone bevolking. Onder deze exclusionaire reacties vallen onder meer contactvermijding en daaraan verbonden residentiële en maatschappelijke segregatie, het afnemen van solidariteit tussen groepen, wederzijds wantrouwen, negatieve vooroordelen en soms zelfs regelrechte discriminatie. Daarnaast heeft een aantal specifieke gebeurtenissen met grote maatschappelijke impact - de aanslagen van 11 september 2001 in de Verenigde Staten, de bomaanslagen in Madrid en Londen en de moord op Theo van Gogh in Nederland - bijgedragen aan negatieve beeldvorming over de islam.

In de context van deze toegenomen maatschappelijke spanningen worden de drie grondrechten vaak ingeroepen om discussies te beslechten. Vaak gaan deze discussies over de bescherming van waarden, dan wel over specifieke uitdrukkingen van religieuze overtuigingen (forum externum) ${ }^{28}$ Rechtszaken gaan bijvoorbeeld over sluiers die het gezicht bedekken op straat, over het dragen van hoofddoeken bij de vervulling van publieke functies, ${ }^{29}$ over religieuze tekens op het werk, de toelaatbaarheid van religieuze reclame, de bouw of instelling van religieuze gebouwen $^{30}$ en het weigeren tot groeten of handen schudden in formele sfeer. ${ }^{31}$ In het navolgende zullen we ons specifiek richten op de botsing tussen de vrijheid van godsdienst en de vrijheid van meningsuiting enerzijds en het gelijkheidsbeginsel anderzijds. We concentreren ons op religieus geïnspireerde uitspraken van religieuze voorgangers die vermeend discriminerend zijn.

\section{De zaken El Moumni en Herbig}

In het kader van vermeende discriminatie door religieuze voorgangers zijn er in Nederland twee belangrijke rechtszaken geweest die nog steeds richtinggevend zijn in vergelijkbare zaken. De eerste zaak dateert uit 2001-2002. Hierin wordt de Marokkaanse imam El Moumni aangeklaagd wegens discriminerende uitspraken jegens homoseksuelen in een tv-uitzending. In de tweede zaak, uit 1998-2003, wordt dominee E.S. Herbig voor eenzelfde overtreding aangeklaagd, maar dan wegens discriminerende uitlatingen in een krant. Het OM heeft naar aanleiding

27 CBS, Ruim 850 duizend islamieten in Nederland, zie www.cbs.nl (24 oktober 2007).

28 Van Bijsterveld 2009, p.144; Oldenhuis e.a. 2007, p. 37.

29 Zie ook B.P. Vermeulen, 'Hoofddoekgebod voor uitsluitend moslimleerkrachten maakt verboden onderscheid op grond van godsdienst', in: S. Burri (red.), Gelijke behandeling: oordelen en commentaar 2005, Nijmegen: Wolf Legal Publishers 2006, p. 425-428.

30 Bijv. de zaak omtrent de bouw van een moskee in Dordrecht. Zie ABRvS 31 juli 2013, ECLI:NL:RVS:2013:566.

31 Zie 'Islamitische docente op openbare school weigert handen te geven' Tijdschrift voor Ambtenarenrecht 2009, november en de zaak tussen de gemeente Rotterdam en de Surinaams-Nederlandse advocaat Mohammed Enait ( $\mathrm{Rb}$. Rotterdam 6 augustus 2008, ECLI:NL:RBROT: 2008:BD9643 en Hof Den Haag 10 april 2012, ECLI:NL:GHSGR:2012:BW1270). 
van deze uitlatingen (strafrechtelijke) vervolging ingesteld. ${ }^{32}$ Opvallend is dat er na deze zaken zeer weinig juridische uitspraken zijn waarin religieuze voorgangers de godsdienstvrijheid inroepen wanneer andere grondrechten in het geding zijn. ${ }^{33}$ Hierna zullen we het verloop van voornoemde zaken kort weergeven, waarbij we ons voornamelijk richten op de afweging tussen de drie grondrechten. In de volgende paragraaf zullen we dan de afweging door de rechtsinstantie analyseren aan de hand van enkele principes die hierin richtinggevend kunnen zijn.

\section{De zaak El Moumni}

Eind 2001 besluit het OM in Rotterdam imam Khalil El Moumni te vervolgen op basis van artikel $137 c^{34}$ en $137 d^{35}$ van het Wetboek van Strafrecht (Sr). Aanleiding is de registratie van 49 aangiften en meldingen van klachten bij het OM over vermeende discriminerende uitspraken die de Rotterdamse imam in het tv-programma NOVA op 3 mei 2001 zou hebben gedaan. In deze uitzending over het gewelddadige gedrag van islamitische jongeren tegen homoseksuelen wordt de imam geïnterviewd over diens islamitische opvattingen aangaande dit onderwerp. In dit interview noemt hij homoseksualiteit een ziekte en kwalificeert hij het als schadelijk voor de Nederlandse samenleving. ${ }^{36}$

Op 8 april 2002 wordt El Moumni door de Rechtbank Rotterdam vrijgesproken. Overtreding van artikel 137c en 137d Sr wordt niet wettig en overtuigend bewezen verklaard. De vraag is nu: welk(e) grondrecht(en) vormde(n) het uitgangspunt van dit vonnis? In de jurisprudentie ${ }^{37}$ wordt als uitgangspunt de vrijheid van meningsuiting genoemd. Men stelt dat dit grondrecht achteraf begrensd kan worden wanneer een uiting in strijd is met de fundamentele rechten van anderen. Hierbij wordt het non-discriminatiebeginsel genoemd als een grondrecht dat eventueel geschonden kan zijn. Inzake artikel 137c Sr erkent de rechtbank dat de uitspraken van de imam beledigend zijn, maar tevens stelt de rechtbank op basis van een arrest van 9 januari 2001 van de Hoge Raad ${ }^{38}$ dat wanneer de uitlatingen direct een religieuze overtuiging uitdrukken, het beledigende karakter van (in

32 Het is voor degenen die hierdoor schade menen te hebben geleden overigens ook mogelijk om deze uitlatingen ter toetsing aan de burgerlijke rechter voor te leggen. Dan is het juridisch beoordelingskader wel anders.

33 Een uitzondering hierop vormt het conflict tussen een Tilburgse pastoor en de gemeente Tilburg over het luiden van de kerkklokken (ABRvS 13 juli 2011, ECLI:NL:RVS:2011:BR1448).

34 Art. 137c Sr: het zich in het openbaar opzettelijk beledigend uitlaten over een groep mensen wegens hun ras, godsdienst of levensovertuiging, hetero- of homoseksuele gerichtheid of lichamelijke, psychische of verstandelijke handicap.

35 Art. 137d Sr: het in het openbaar aanzetten tot haat, discriminatie of gewelddadig optreden tegen persoon of goed van mensen wegens hun ras, godsdienst of levensovertuiging, hetero- of homoseksuele gerichtheid of lichamelijke, psychische of verstandelijke handicap.

36 In het transcript van het interview staat letterlijk: 'Homoseksualiteit blijft niet beperkt tot de mensen die deze ziekte hebben maar kan zich verspreiden. De Nederlandse samenleving is multicultureel. Als die ziekte zich verspreidt, kan iedereen besmet raken.' Zie 'Het interview met imam El Moumni', NOVA 23 januari 2003, www.novatv.nl (zoek op El Moumni).

37 Rb. Rotterdam 8 april 2002, NJCM-Bulletin 2002, p.1012.

38 ECLI:NL:PHR:2001:AA9368. Zie NJCM-Bulletin 2002, p.1013 en HR, NJ 2001/203. 
beginsel) beledigende uitlatingen komt te vervallen. Dan beschermt de godsdienstvrijheid de verdachte tegen een strafrechtelijke procedure.

Aangezien de uitspraken van El Moumni herleid kunnen worden naar fundamentele geschriften van de islam zoals de Koran en de soenna, vallen zijn uitlatingen over homoseksualiteit onder de vrijheid van godsdienst. Ook artikel 137d Sr is niet van toepassing vanwege de context waarbinnen de uitlatingen zijn gedaan. De imam heeft namelijk in een niet uitgezonden gedeelte van het interview voor de rechtbank voldoende duidelijk gemaakt dat het niet zijn bedoeling was om aan te zetten tot haat, discriminatie of geweld. ${ }^{39}$

Het OM gaat echter in hoger beroep. Op 18 november 2002 wordt het vonnis van de Rechtbank Rotterdam bevestigd door het Gerechtshof Den Haag met aanvulling en verbetering van gronden. ${ }^{40} \mathrm{Als}$ extra criterium wordt de wijze waarop de uitlating is gedaan, gehanteerd: valt het uitdragen van de geloofsovertuiging binnen de grenzen van het aanvaardbare? Het gerechtshof is van mening dat de imam zijn geloofsopvatting onder meer op grond van het verkeerd uit het Arabisch vertaalde 'marat' ${ }^{\text {'1 }}$ binnen de grenzen van het aanvaardbare heeft geuit. Daarmee wordt El Moumni nogmaals vrijgesproken.

\section{De zaak Herbig}

Op 16 januari 1998 verschijnt in De Twentsche Courant Tubantia ${ }^{42}$ een ingezonden brief van pinkstervoorganger E.S. Herbig waarin hij pedofilie, homofilie en polygamie gelijkstelt aan 'vieze en vuile zonden'. ${ }^{43}$ Op grond van artikel 137c Sr wordt een klacht tegen de dominee ingediend wegens opzettelijke belediging van homoseksuelen. De politierechter te Almelo spreekt de dominee echter op 22 november 1999 vrij. Hierop gaat de officier van justitie in hoger beroep bij het Arnhemse gerechtshof, waar het vonnis van de politierechter wordt bevestigd. Interessant is de motivatie van het vonnis. Het hof oordeelt dat de uitlating op zichzelf beledigend is, maar haar beledigend karakter verliest omdat zij direct uitdrukking geeft aan de geloofsopvatting van de dominee dat homofilie een zonde is. ${ }^{44}$ Dit leidt men af uit het feit dat de dominee homofilie afwijst als strijdig met en in uitdrukkelijke verwijzing naar de Bijbel en dat hij de brief met 'Rev. E.S.H.' heeft ondertekend. Volgens het gerechtshof probeert de dominee vanuit zijn geloofsopvatting de mensheid te waarschuwen. Hierbij vallen zijn uitlatingen binnen de grenzen van het aanvaardbare, omdat in Leviticus 18:22 homofilie een gruwel(daad) of gruwelijke zonde wordt genoemd, waarvan 'vieze en vuile zonde' afgeleid kan

39 El Moumni stelt namelijk: 'De islam verbiedt agressie tegen wie dan ook, ongeacht z'n omstandigheden en de ziekte die hij heeft.' Zie 'Het interview met imam El Moumni', www.novatv.nl (23 januari 2003).

40 Hof Den Haag 18 november 2002, ECLI:NL:GHSGR:2002:AF0667.

41 In de NOVA-uitzending werd 'marat' vertaald als 'ziekte', terwijl een juiste vertaling 'afwijking' of 'opvoedingsziekte' zou zijn.

42 De Twentsche Courant Tubantia is een regionaal dagblad, opgericht in 1872, dat in Twente, de Achterhoek, Salland en enkele Duitse plaatsen verschijnt.

43 Letterlijk stelt E.S. Herbig: 'Zonde is geen zonde meer en men moet maar tolerant zijn in de richting van vieze en vuile zonden.' Zie voor de volledige tekst: Tubantia 16 januari 1998, rubriek 'Lezers schrijven'. 
worden. De conclusie van het hof is dan ook dat de uitlatingen van de dominee dienden ter aanduiding van zijn geloofsopvatting dat homofilie een zonde is, en daarom worden zijn uitlatingen op grond van de godsdienstvrijheid niet als beledigend volgens artikel 137c Sr aangemerkt.

Het OM gaat echter in cassatie en brengt de zaak voor de Hoge Raad, die moet beoordelen of het hof een juiste rechtsopvatting aangaande de term beledigend heeft gehanteerd. ${ }^{45}$ De Hoge Raad stelt dat belediging van een groep mensen wegens hun homoseksuele gerichtheid vastgesteld dient te worden aan de hand van drie criteria: de aard van de uitlatingen, de eventuele onderlinge samenhang en de context waarin de uitlatingen zijn gedaan. Hierbij merkt de Hoge Raad op dat de regering bij de wijziging van artikel 137c Sr heeft gesteld dat het artikel terughoudend moet worden toegepast. Dit betekent dat er ruimte moet zijn voor kritiek op opvattingen en gedragingen, ook al is deze kritiek beledigend of kwetsend. Strafbaar zijn kritische uitlatingen waarin ook conclusies worden getrokken ten aanzien van een groep mensen.

Aangaande de aard van de uitlatingen wordt door de Hoge Raad als beledigend ${ }^{46}$ aangemerkt dat homofilie een vieze en vuile zonde wordt genoemd en dat het op één lijn geplaatst wordt met pedofilie en polygamie, twee vormen van seksuele gedragingen die door het Wetboek van Strafrecht worden verboden. Men stelt dat de term 'vies en vuil' een onnodig grievende toevoeging is, die homofilie als minderwaardig en onwaardig afschildert. De dominee had zijn boodschap ook duidelijk kunnen maken door enkel over homoseksualiteit als zonde te spreken. Hierdoor vallen zijn uitlatingen binnen de grenzen van artikel 137c Sr. Van onderlinge samenhang is in deze casus geen sprake, omdat dit alleen van toepassing is als de uitspraken geïsoleerd bezien niet beledigend zouden zijn.

Inzake de vraag of de context het beledigende karakter van de uitspraken wegneemt, trekt de Hoge Raad een parallel met de zaak Van Dijke, waarin de christelijke parlementariër Leen van Dijke werd aangeklaagd wegens discriminatie omdat hij in een interview de vraag stelde waarom een homoseksueel beter zou zijn dan een dief. ${ }^{47}$ Op grond van de vrijheid van godsdienst en vrijheid van meningsuiting stond het Van Dijke vrij zijn geloofsverkondiging uit te dragen. De Hoge Raad duidt echter op de verschillen met de zaak Herbig ${ }^{48}$ en komt tot de conclusie dat de uitlatingen van dominee Herbig niet voldoen aan de criteria van de zaak Van Dijke. Desalniettemin acht de Hoge Raad de overwegingen van het Arnhemse gerechtshof aangaande de context van de uitlatingen juist, namelijk dat deze dienden ter aanduiding van Herbigs geloofsopvatting dat homofilie een zonde is en dat hiervoor voldoende aanwijzingen zijn in diens brief. De religieuze uiting wordt op grond van de context niet beledigend bevonden en dominee Herbig wordt definitief vrijgesproken.

6 Beledigend in de zin van het 'aantasten van de eigenwaarde' of het 'in diskrediet brengen van een groep mensen' wegens hun homoseksuele gerichtheid.

47 Hof Den Haag 9 juni 1999, AB 1999, 328.

48 O.a. twijfel over de rol van het maatschappelijk debat en de aanvaardbaarheid van de termen van de dominee. 


\section{Voorgangers en discriminatie: afwegingsprincipes}

Hoe komt de rechtsinstantie tot de afweging van grondrechten wanneer deze met elkaar botsen? Aangezien er geen hiërarchie in grondrechten bestaat, zoekt de rechter in elke zaak naar de dunne lijn tussen afwijkend gedrag dat nog toelaatbaar is op grond van de godsdienstvrijheid, en laakbaar gedrag dat de 'verantwoordelijkheid voor de wet' schendt. ${ }^{49}$ Vervolgens zoekt de rechter naar een evenwicht tussen de godsdienstvrijheid, de vrijheid van meningsuiting, het gelijkheidsbeginsel en de strafbepaling. De tendens is dat de vrijheid van meningsuiting boven het discriminatieverbod wordt gesteld op grond van de gedachte dat het kunnen uiten van religieuze gevoelens mogelijk moet zijn in een pluriforme samenleving.

De afweging van grondrechten moet nauwkeurig en gefundeerd gebeuren, maar heldere richtinggevende principes ontbreken vaak. Jan Piet van Berkel heeft in 2012 in zijn artikel in het Tijdschrift voor Religie, Recht en Beleid een mogelijk richtinggevend denkkader geschetst als hulpmiddel bij het afwegen van botsende belangen. ${ }^{50}$ Hierin onderscheidt hij een aantal vragen die een rol kunnen spelen in de belangenafweging wanneer de godsdienstvrijheid tegenover een ander grondrecht staat. Bijvoorbeeld: wordt een ander door het gecontesteerde gedrag materieel benadeeld? Is de aantasting van het andere belang groot? Is bij een verbod de aantasting van de godsdienstvrijheid groot?

In de beoordeling van de hiervoor gepresenteerde casussen zijn de volgende principes te onderscheiden. Het eerste beginsel van de interpretatieve terughoudendheid is een meer algemeen juridische principe dat in de jurisprudentie expliciet wordt vermeld; het tweede en derde principe betreffen de persoon van de religieuze voorganger en zijn eerder impliciet aanwezig.

Ten eerste het beginsel van de interpretatieve terughoudendheid. In de afweging tussen de grondrechten moet de rechter eerst bepalen of het gecontesteerde gedrag onderdeel is van het belijden van een godsdienst en dus valt onder de godsdienstvrijheid. Omdat de maatschappelijke consensus over wat religie is verdwijnt, wordt de rechter steeds vaker gedwongen hier een oordeel over te vellen. Maar de scheiding van kerk en staat houdt in dat de rechtsinstantie geen uitspraken mag doen over de inhoud van godsdienst. ${ }^{51} \mathrm{Om}$ dit dilemma op te lossen kijkt de rechter aan de hand van objectieve maatstaven of een gedraging een directe uitdrukking is van een godsdienst of levensovertuiging. Als er twijfel bestaat, wordt er gekeken naar de subjectieve beleving van de betrokkene. Wanneer deze meent uit religieuze overtuiging te handelen, stelt de rechter zich principieel terughoudend op om dit te betwisten. ${ }^{52}$

49 Art. 6 lid 1 Gw. Zie ook Oldenhuis e.a. 2007, p. 35.

50 J.P. van Berkel, 'Botsende belangen bij religieuze uitingen en de relevantie van het compromis', Tijdschrift voor Religie, Recht en Beleid 2012-2, p. 46-58.

51 Het is niet aan overheidsorganen om uit te maken wat een gelovige of een religieuze organisatie onder het belijden van diens godsdienst verstaat. Zie L.C. Drimmelen \& T.J. Van der Ploeg, Kerk en Recht, Utrecht: Lemma 2004, p.79. 
De andere afwegingsprincipes betreffen de positie die de voorganger bekleedt en hangen nauw met elkaar samen, maar zijn niettemin van elkaar te onderscheiden. Het eerste is autoriteit. Een voorganger bekleedt in zekere mate een gezagspositie, zeker ten opzichte van zijn (al dan niet plaatselijk) religieus genootschap. Hoewel de grootte en de reikwijdte van dit gezag met de secularisering zijn afgenomen, is het nog steeds in zekere mate aanwezig. In rechtszaken betreffende controversiele religieuze uitingen die een grote reikwijdte hebben middels tv (El Moumni), radio of krant (Herbig), is autoriteit als afwegingsprincipe impliciet aanwezig. ${ }^{53}$

Autoriteit kan worden versterkt door de eventuele afhankelijkheidsrelatie ten opzichte van de voorganger. Vergelijkbaar met de relatie tussen psycholoog en client, waarin een psycholoog verantwoordelijkheid draagt voor het psychisch welzijn van zijn cliënt, wordt een voorganger doorgaans medeverantwoordelijk gehouden voor het geestelijk welzijn van de leden van zijn geloofsgemeenschap. Een gelovige moet en mag de garantie hebben dat een voorganger diens belang voorop heeft staan. Religieuze uitingen van een voorganger kunnen daarom ook door de leden van een geloofsgemeenschap als dwingender worden ervaren dan door derden in de samenleving. Dit kan de religieuze uiting een grotere impact geven. Autoriteit en afhankelijkheid kunnen door de rechter worden meegewogen in de positionering van de voorganger. Ze maken duidelijk dat de religieuze voorganger onlosmakelijk verbonden is met zijn religieuze gemeenschap. Dit leidt ook tot de volgende vraag: wie is eigenlijk juridisch verantwoordelijk wanneer een voorganger zegt de geloofsleer uit te dragen? De geloofsgemeenschap of de voorganger? Dit is een lastige kwestie, die vaak impliciet in de afweging aanwezig is. Niettemin toont dit het belang van de positionering van de religieuze voorganger in geval van religieus gefundeerde discriminatie.

\section{Conclusie}

In hoeverre kan een religieuze voorganger zich beroepen op de godsdienstvrijheid wanneer zijn uitspraken botsen met de grondrechten van anderen? Het antwoord op deze vraag is afhankelijk van meerdere factoren. Allereerst van de juridische positie van de grondrechten die een rol spelen in het conflict. De juridische positie wordt onder meer bepaald door de historische en maatschappelijke verankering van de grondrechten en de daaruit voortgekomen formulering in (inter)nationale wetgeving. Voor de godsdienstvrijheid is bijvoorbeeld het onderscheid tussen forum internum en forum externum van groot belang. In de juridische afweging zal worden gekeken of een religieuze uiting valt onder de vrijheid om een religieuze overtuiging te hebben of onder de vrijheid om er uitdrukking aan te geven. Doorgaans kent het forum internum een grote mate van bescherming, zoals ook blijkt uit de juridische beoordeling van de zaken El Moumni en Herbig.

53 Autoriteit en/of maatschappelijk aanzien worden niet enkel meegenomen in zaken aangaande religieuze voorgangers. Zo werd in de zaak tegen de politicus Van Dijke, wegens zijn discriminerende uitspraken jegens homoseksuelen, zijn positie als lid van de Tweede Kamer meegenomen in de afweging. Zie Hof Den Haag 9 juni 1999, AB 1999, 328. 
Ten tweede speelt de maatschappelijke context een rol. Door de toegenomen diversiteit in religieuze en culturele normen en waarden is de maatschappelijke consensus over religie grotendeels verdwenen. Hierdoor wordt het toepassingsbereik van de godsdienstvrijheid minder duidelijk. Verder is er in zekere zin sprake van een maatschappelijke polarisering, onder meer gevoed door de negatieve aandacht voor radicale vormen van religie. Beide maatschappelijke ontwikkelingen dragen bij aan toenemende aandacht voor de botsing van grondrechten, hoewel het aantal rechtszaken verrassend beperkt blijft. Ondanks secularisering en pluralisering lijkt de godsdienstvrijheid in de afweging van grondrechten een sterke positie te behouden. ${ }^{54}$ Samen met vrijheid van meningsuiting wordt ze van belang geacht om de pluraliteit van de samenleving te beschermen.

Ten derde zijn voor de afweging van de rechter de precieze omstandigheden van de religieuze uiting van groot belang. In de zaak tegen dominee Herbig was het twistpunt voornamelijk de toelaatbaarheid van de 'grove' formulering van zijn religieuze overtuiging. Voor de gereformeerde dominee in Ede vormde de context waarbinnen diens gebed plaatsvond de grond voor vervolging, terwijl imam El Moumni juist vrijgesproken werd wegens de samenhang van zijn religieuze uiting met andere uitspraken in het interview. Op grond van literatuur en jurisprudentie onderscheiden we grofweg de volgende richtinggevende principes: de interpretatieve terughoudendheid aangaande religie, de autoriteit van de voorganger en de eventuele afhankelijkheidspositie tegenover deze voorganger. Daarbij zoekt de rechter antwoord op de volgende vragen: valt de uiting wel onder de godsdienstvrijheid, op welke wijze vond de religieuze uiting plaats, en wat is de positie van de voorganger door wie de uiting werd gedaan? Een kritische reflectie op deze principes in het dagelijkse leven buiten de rechtszaal is nodig om spanningen in de samenleving te vermijden. En vooralsnog blijkt dat relatief goed te lukken, want het is opvallend dat er sinds 2003 maar weinig rechtszaken terug te vinden zijn waarin de godsdienstvrijheid van religieuze voorgangers botst met andere grondrechten. 